\title{
Examining climate change impact on the variability of ground water level: A case study of Ahmednagar district, India
}

\author{
N A Sivarajan, Anoop Kumar Mishra*, Mohammd Rafiq, V Nagraju \\ and SAGARIKA CHANDRA \\ Centre for Remote Sensing and Geoinformatics, Sathyabama Institute of Science and Technology, \\ Chennai 600 119, India. \\ *Corresponding author. e-mail: daksha112@gmail.com
}

MS received 8 May 2018; revised 10 December 2018; accepted 11 December 2018; published online 8 May 2019

This study focuses on examination of variability in the depth to water below ground level (bgl) from 1996 to 2016 in Ahmednagar district of Maharashtra, India in changing climate. Spatial variability of groundwater depth was mapped and classified as shallow, normal, deep and moderate using GIS modeling. Groundwater decline rates during successive decades were examined and critical areas with a significant fall in groundwater levels (GWL) were detected. Present study also focuses on examination of block-wise variability of GWL. Ground water level shows significant variability during 1996-2016 at confidence level 95\%. The long term ground water level fluctuation indicates that water levels in major parts of the study area have declined drastically. The depth to ground water in major parts of the study area ranges between 6 and $15 \mathrm{~m} \mathrm{bgl}$ except in Parner and Shrirampur blocks. Furthermore, depth to water level is $>15 \mathrm{mbgl}$ over Sangamner block during the drought year 2004. Present study reports a significant decadal increase of about $0.7 \mathrm{~m}$ in water leval decline over the study area. Groundwater depletion over the study area has been observed with decrease in groundwater recharge and increase in temperature and urbanization. Groundwater depletion shows coherent variability with temperature. Our results report a significant decrease of about $0.61 \mathrm{~cm} /$ year in ground water recharge as a result of decrease in precipitation and a decadal increase of about $0.1^{\circ} \mathrm{C}$ in temperature over the study area. Evapotranspiration (ET) shows yearly increasing trend of about $9.6 \mathrm{~mm}$ over the study area. Results reported in this study highlight the importance of sustainable groundwater resource management over the study area.

Keywords. Groundwater; climate change; spatial variation; rainfall; temperature.

\section{Introduction}

Groundwater is an important source of water for domestic and agriculture usage. Rapid expansion and usage of groundwater-based irrigation system to feed the growing population and improper irrigation systems have caused overexploitation of groundwater at a very rapid rate. Overexploitation has resulted in lowering of the groundwater table, decrease in the well yield, and, consequently, increase in crop production rate and cost.

Climate change is expected to have a significant impact on available water resources by changing 
the groundwater recharge (Salem et al. 2017). Climate has driven the hydrological cycle and any change in climate has significant changes in the hydrological cycle. Climate change also affects the availability of water by altering the water sources (Mishra and Rafiq 2017; Rafiq and Mishra 2016). Climate change caused a significant change in precipitation patterns over India (Goswami et al. 2006; Mishra and Liu 2014; Rafiq and Mishra 2018). This change includes increase in heavy precipitation causing floods and decrease in low and moderate precipitation resulting in droughts. Changed precipitation pattern also affects evapotranspiration; surface runoff, ground water recharge, and irrigation demand (Wang et al. 2016; Salem et al. 2017). Higher temperature causes increase in evapotranspiration (ET) resulting in deeper groundwater level (Gunawardhana and Kazama 2012). It has been observed that there has been an increase in irrigation demand over the many parts of the globe as a result of changing climate (Wang et al. 2016). Groundwater is the major source of irrigation. Thus climate change may have a very significant impact on ground water (Taylor et al. 2013).

Goyal et al. (2010) examined varibility of ground water level over a district in Haryana and reported decline in ground water level over the study area. Thakur and Thomas (2011) reported decline in ground water level over a district in Madhya Pradesh. Panda et al. (2012) used water table records of about 555 monitoring wells to report large decline in ground water level over Gujarat. Patle et al. (2015) reported an annual decline of about $0.267 \mathrm{~m}$ in ground water level over Karnal district of Haryana. Singh and Kasana (2017) examined data from 893 monitoring wells over Haryana to report an annual decline of about $32 \mathrm{~cm}$.

This study aims to examine climate change impact on groundwater level in Ahmednagar, Maharashtra. Variability and spatial pattern of GWL variations are explored. Impact of the climate change on groundwater level is also examined. For this purpose temperature, ET, ground water recharge and urbanization data were explored and related to ground water level variability over the study area.

\section{Study area and well location}

Ahmednagar district is situated in the central part of the Maharashtra and lies between $18^{\circ} 19^{\prime}-19^{\circ} 59^{\prime} \mathrm{N}$ latitude and $73^{\circ} 37^{\prime}-75^{\circ} 32^{\prime} \mathrm{E}$ longitude. It is surrounded by Nashik and Aurangabad districts to the north, Beed and Osmanabad districts to the east, Solapur and Pune districts to the south and Pune and Thane districts to the west. Topographically the district can be divided into three parts, viz., the Sahyadri ranges, plateau region and Bhima, Godavari basins. It is the largest district of Maharashtra state in terms of area. It covers an area of $17048 \mathrm{~km}^{2}$ which is about $5.66 \%$ of the state.

There are 67 central groundwater board (CGWB) observation dug wells in this district. Out of these dug wells, only 43 wells have continuous record of ground water level for 2 decades. Location of these wells has shown as red dots in figure 1.

\section{Data and methodology}

Datasets from different sources were utilized for various analyses. These datasets include ground water level of $42 \mathrm{dug}$ wells procured from Central Ground Water Board (CGWB) during 19962016. Data were digitized in a GIS interface using ArcGIS software and spatial distribution/changes in GWL were analyzed. Landsat ETM+ data of 2000 was utilized to generate land use, land cover (LU/LC) map of the study area. For detecting the changes in $\mathrm{LU} / \mathrm{LC}$, data from Bhuvan portal was used (http://bhuvan.nrsc.gov.in) for the years 2005-2006, and 2011-2012. We also have used Landsat ETM+ data for the year 2000-2001. Daily data of precipitation, temperature and ET were also used in the study. Temperature and Evapotranspiration data from Modern-Era Retrospective analysis for Research and Applications (MERRA) during 1996-2016 were also utilized in the study. Precipitation data from 1998 to 2016 was also obtained from Tropical Rainfall Measuring Mission (TRMM).

Groundwater recharge was derived using a criteria proposed by Misstear et al. (2009) and adopted by Adeleke et al. (2015). Following equation was proposed for estimating ground water recharge:

$$
R=1.35(P-14)^{0.5}
$$

where $R=$ net recharge due to precipitation and $P=$ precipitation (in inches).

Socio-economic data from the census of India during 1991, 2001 and 2011 were utilized for analyzing urbanization aspect over the study area. 


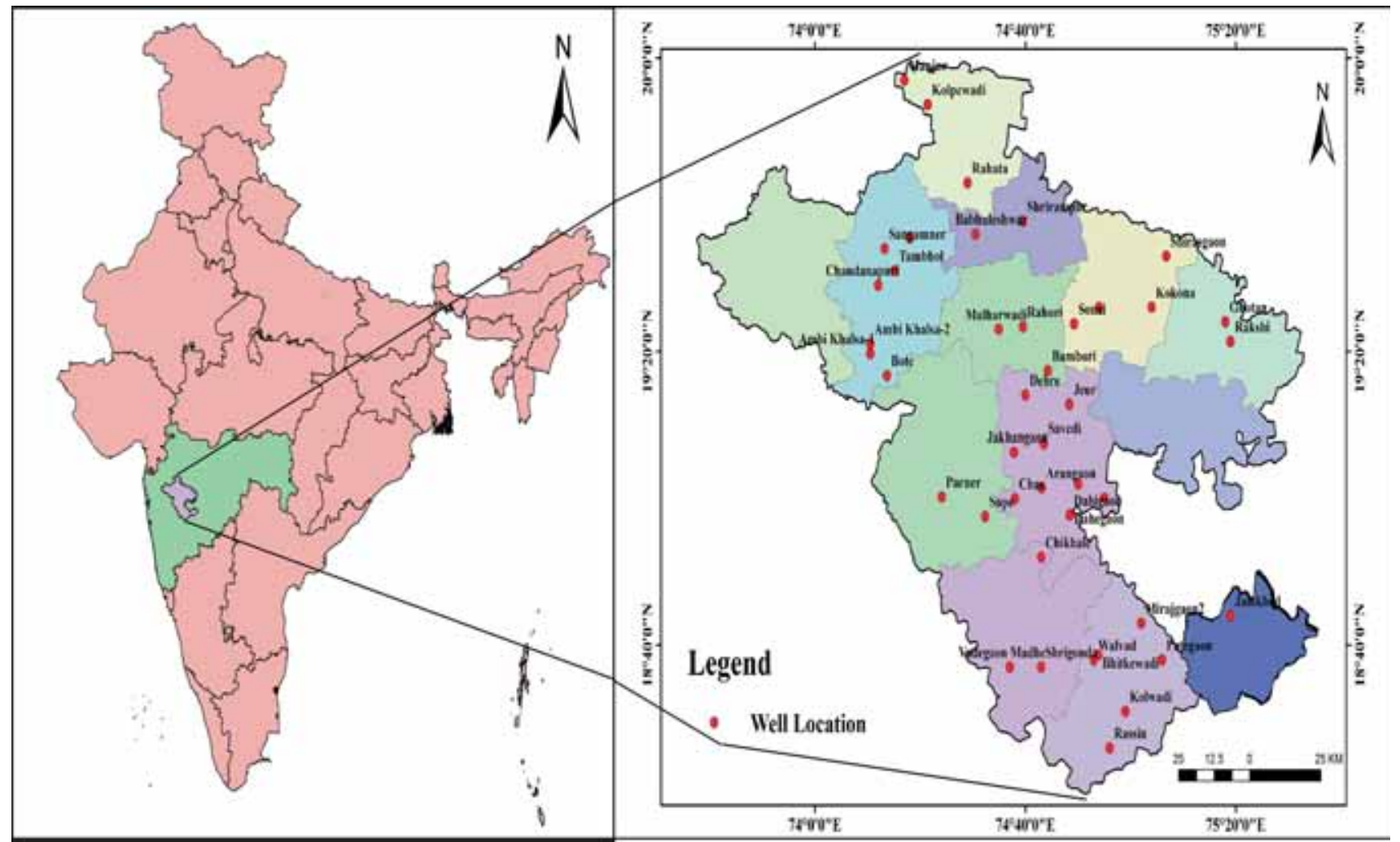

Figure 1. Index map of the study area and location of wells.

GWL maps were prepared for exploring seasonal and annual variability using ArcGIS.

\section{Results and discussions}

\subsection{Spatial variation of GWL}

Figure 2 shows spatial variations of GWL at intervals of five years from 1996 to 2016. Comparison of GWL maps for the years 1996, 2001, 2006, 2011 and 2016 reveals a non-uniform groundwater level variability. Four categories were classified namely, shallow, normal, moderate and deep using criterion defined by CGWB. There is areal shift from shallow to deep category, indicating significant increase in areas of critical category zone. It can be seen that area with shallow category has been decreased by about $63.74 \%$ from 1996 to 2016 . There is five fold increase in areas of deep category from 1996 to 2016, indicating alarming decline in ground water level over study area. This decrease highlights the importance of artificial ground water recharge.

Figure 3 shows the variation of ground water level of each blocks of study area from 1996 to 2016. Significant interannual variation in ground water level can be observed from the figure. Long term

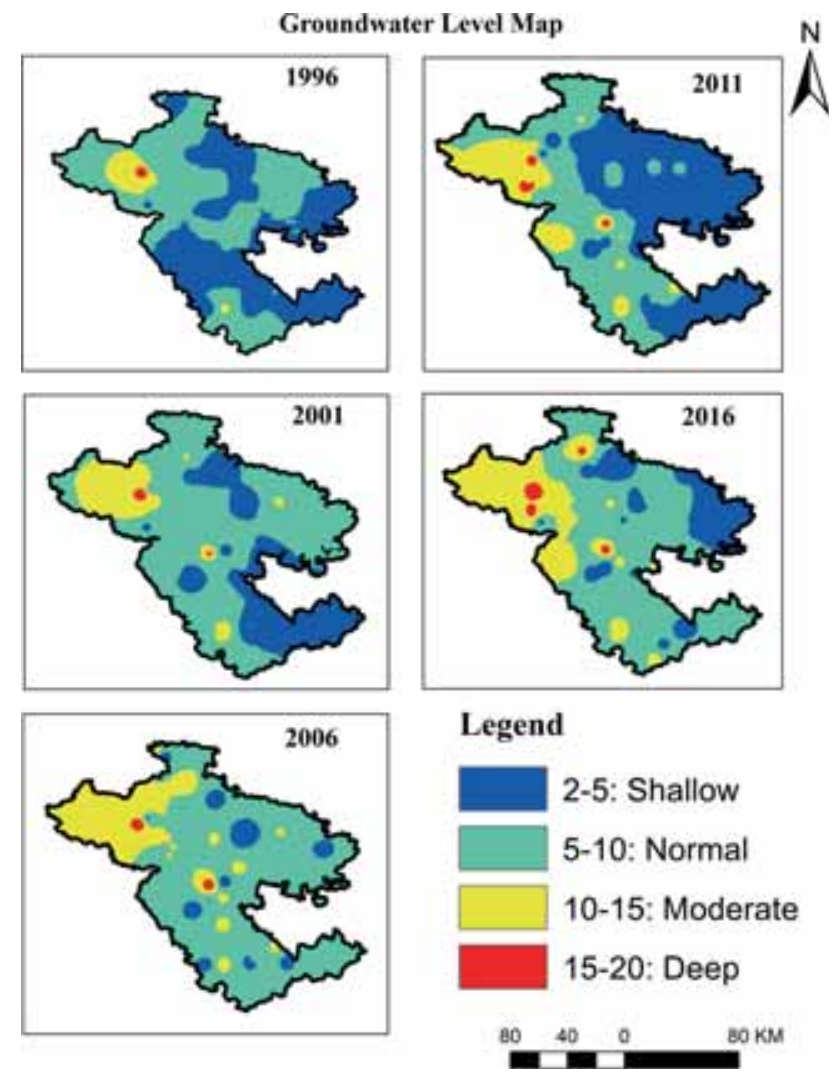

Figure 2. Spatial variability of groundwater depth in Ahmednagar district from 1996 to 2016. 


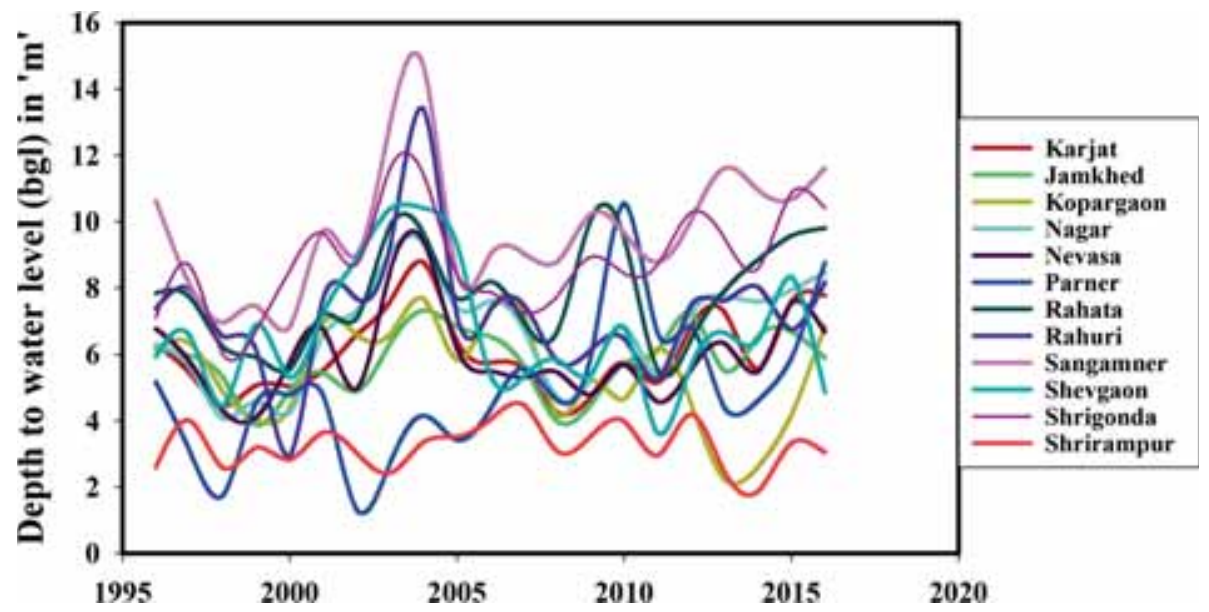

Figure 3. Block-wise variations of average depth to water level (bgl).

Table 1. Block-wise average depth to water level and groundwater depletion.

\begin{tabular}{|c|c|c|c|c|c|c|}
\hline \multirow[b]{2}{*}{ Sl. no. } & \multirow[b]{2}{*}{ Blocks } & \multicolumn{5}{|c|}{ Average annual depth to water level (bgl) (m) } \\
\hline & & 1996 & 2001 & 2006 & 2011 & 2016 \\
\hline 1 & Karjat & 6.28 & 5.52 & 5.75 & 5.15 & 7.72 \\
\hline 2 & Jamkhed & 6.15 & 5.43 & 6.53 & 6.11 & 5.90 \\
\hline 3 & Kopargaon & 6.14 & 6.96 & 7.36 & 6.18 & 6.83 \\
\hline 4 & Ahmednagar & 6.29 & 6.59 & 7.62 & 5.37 & 8.47 \\
\hline 5 & Nevasa & 6.77 & 6.76 & 5.49 & 4.57 & 6.69 \\
\hline 6 & Parner & 5.16 & 4.77 & 4.35 & 6.63 & 8.78 \\
\hline 7 & Rahata & 7.84 & 7.21 & 8.2 & 5.54 & 9.81 \\
\hline 8 & Rahuri & 7.38 & 7.7 & 7.35 & 5.26 & 8.18 \\
\hline 9 & Sangamner & 10.63 & 9.73 & 9.03 & 8.79 & 11.62 \\
\hline 10 & Shevgaon & 5.94 & 7.25 & 5.37 & 3.63 & 4.86 \\
\hline 11 & Shrigonda & 7.11 & 9.65 & 7.87 & 8.71 & 10.42 \\
\hline 12 & Shrirampur & 2.6 & 3.65 & 4.04 & 2.95 & 3.05 \\
\hline \multicolumn{2}{|c|}{ District average } & 6.53 & 6.77 & 6.58 & 5.74 & 8 \\
\hline
\end{tabular}

ground water level fluctuation indicates that water levels in major parts of the study area have declined drastically. The depth to ground water in most of the blocks ranges between 6 and $15 \mathrm{~m}$ below ground level (bgl) except in Parner and Shrirampur block. It can be seen that depth to water level is $>15 \mathrm{mbgl}$ over Sangamner block during the drought year 2004. Parner block shows least depth of about $1 \mathrm{mbgl}$ in ground water level during 2002.

Rate of ground water level decline was maximum over Parner block $(0.18 \mathrm{~m} / \mathrm{yr})$, followed by Shrigonda, Ahmednagar, Rahata and Karjat blocks. Jamkhed, Kopargaon, Nevas Rahuri, Sangamner, Shevgaon and Shrirampur blocks show less variability in groundwater level. Table 1 shows depth of ground water level over each block as well as over entire district. Average ground water level over study area has been reported as $6.53 \mathrm{mbgl}$ in 1996 and declined to about $8 \mathrm{mbgl}$ in 2016 .
The study area shows a significant annual decline of about $0.07 \mathrm{mbgl}$ in ground water level. There has been an increase of about $78 \%$ in areas showing increase in depletion of ground water level over study area. It can also be noted that most of the wells show decline in ground water level from 1996 to 2016 (figure 4). The groundwater depletion in each block at successive intervals of five years is given in table 1.

Ground water level is greatly affected by ground water recharge which in turn is governed by rainfall. Ahmednagar district is one of the drought prone districts of Maharashtra. Figure 5 shows the variability of ground water level of study area during pre-monsoon, post-monsoon and entire year. It can be seen that ground water level shows high variability over study area.

Sharp peaks in ground water level decline can be observed during drought years (2002-2004 and 2009-2010) causing decreased ground water 


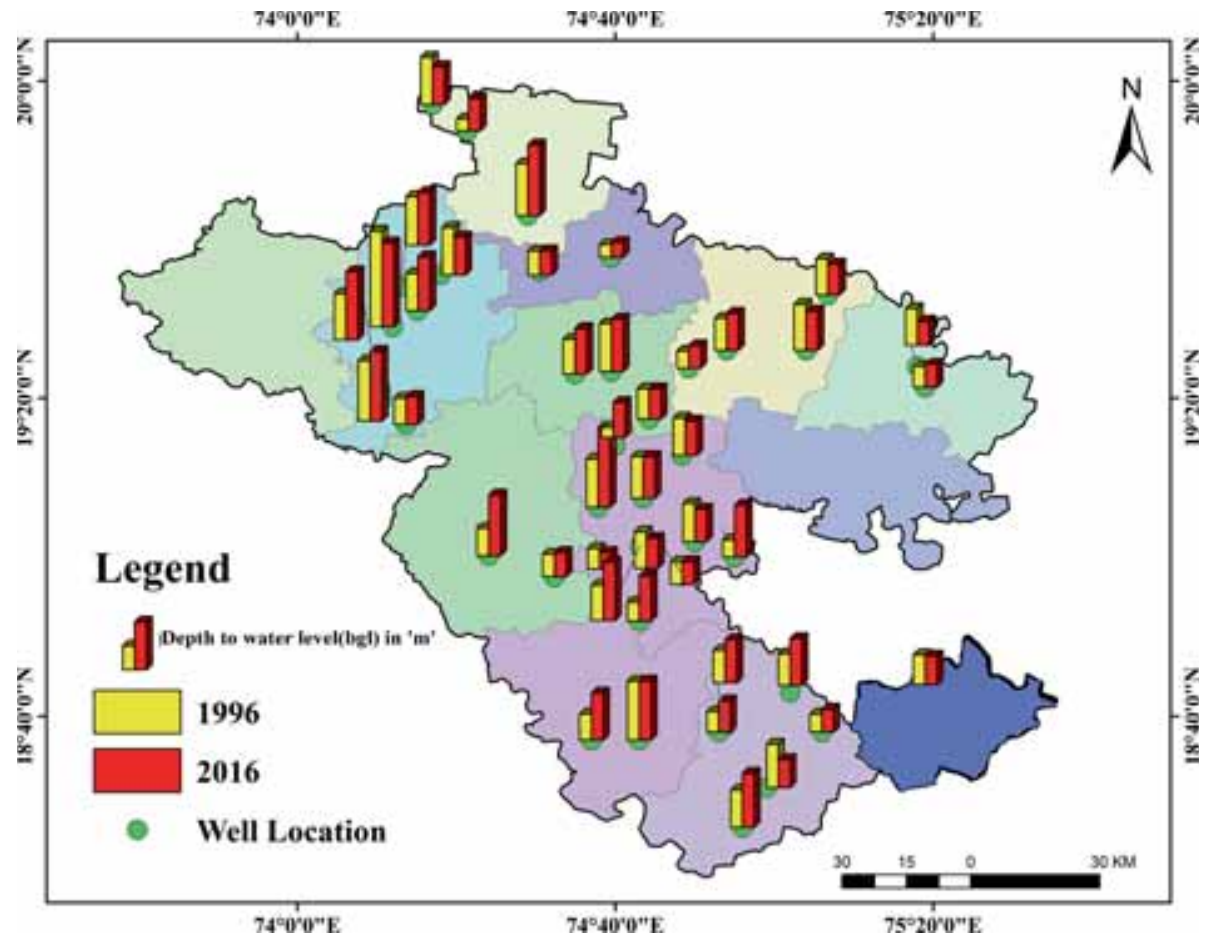

Figure 4. Groundwater depth variation from 1996 to 2016 over each location.

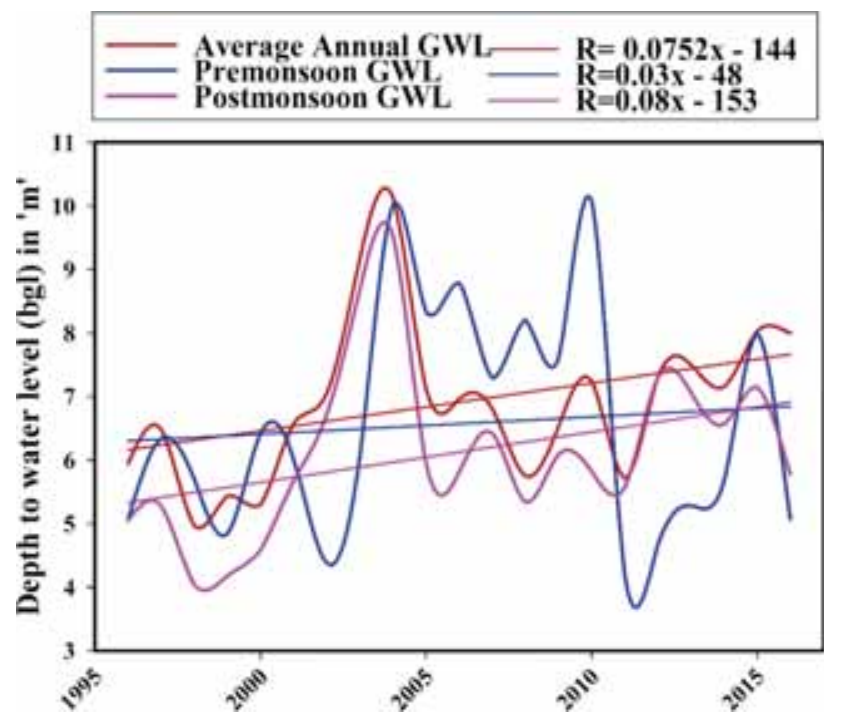

Figure 5. Variability of average depth to water level (bgl) in Ahmednagar district.

recharge over study area. Troughs are observed with good rainy years recharging ground water.

\subsection{Climate change impact on ground water level}

Groundwater level may get affected by the consequence of climate change. Climate change is expected to have impact on hydrological cycle, affecting ground water recharge to ground water level. Past studies report a change in precipitation pattern as a consequence of warming over India (Mishra and Liu 2014). This change includes a decrease in low and moderate precipitation causing droughts over India. Precipitation affects ground water recharge and thus has a significant impact on ground water level (Yagbasan 2016). Ground water recharge has been calculated using technique described in methodology section. Figure 6 shows variation of ground water level with precipitation and ground water recharge. It can be seen that study area shows decreasing trend in precipitation and ground water recharge. It can also be seen that decrease in ground water recharge may cause an increase in depletion of ground water level. Peaks and troughs in ground water show a near coherent variation with troughs and peaks in ground water recharge.

Decreased precipitation over study area has resulted in decrease in ground water recharge. Ground water recharge shows a significant decadal reduction of about $0.61 \mathrm{~cm}$ over study area causing depletion in ground water level.

Variation of ground water level with temperature and ET is illustrated in figure 7. It may be noted that ground water level shows a near coherent variation with temperature and ET. Decadal increase of about $0.1^{\circ} \mathrm{C}$ causes an annual increase of about $9.6 \mathrm{~mm}$ in ET. Trends in ET are significant at 95\% confidence level. Increased ET is responsible 


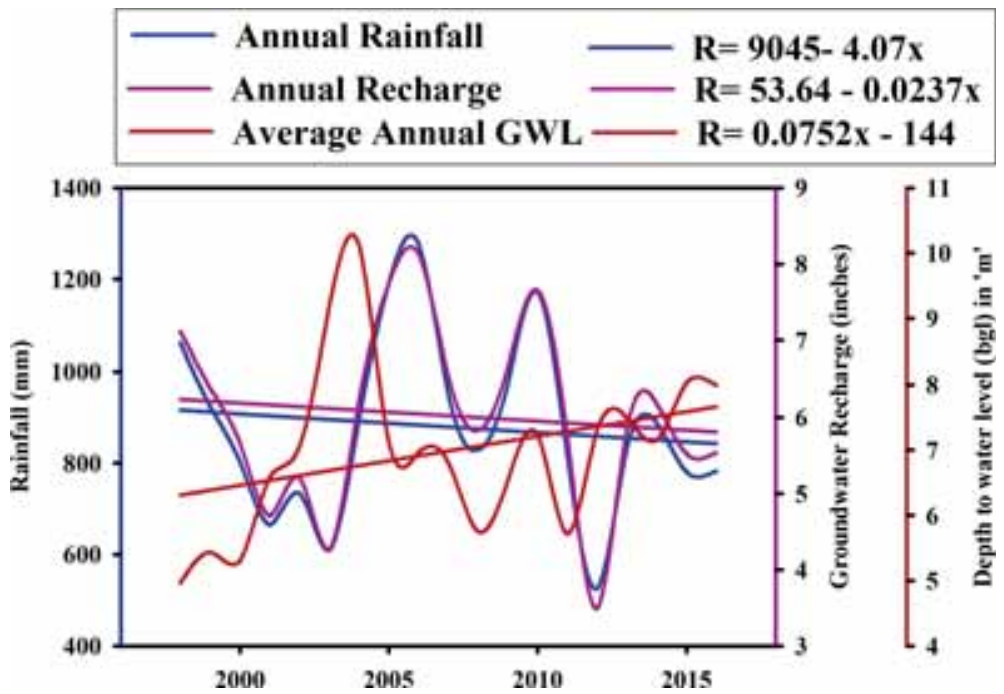

Figure 6. Variability of groundwater level with precipitation and groundwater recharge.

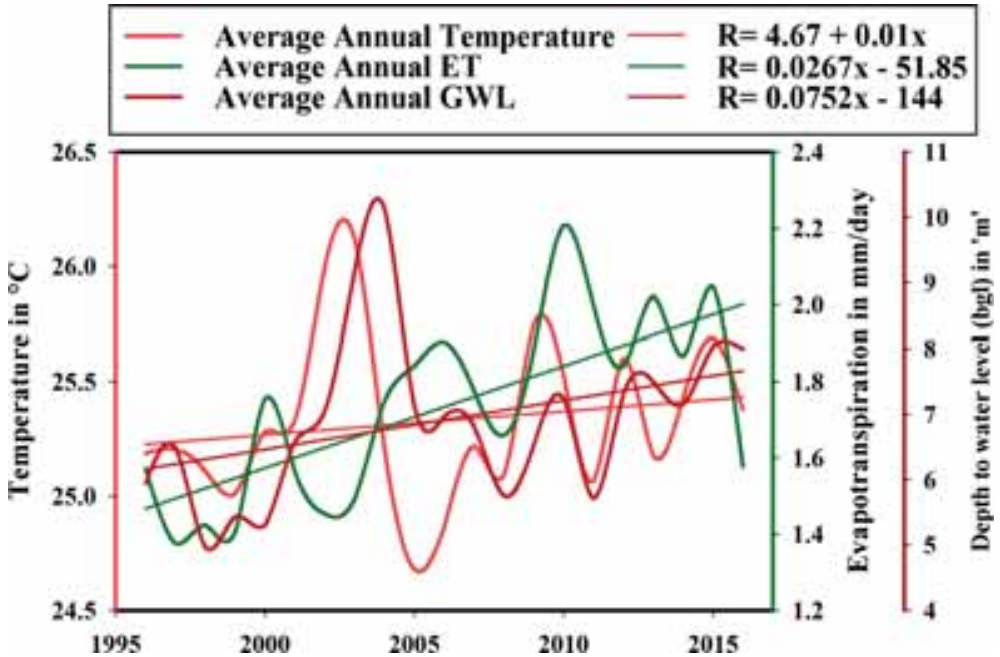

Figure 7. Variability of average annual groundwater level (mbgl) with average annual temperature and evapotranspiration.

Table 2. Land use and land cover classification.

\begin{tabular}{|c|c|c|c|c|c|c|}
\hline LULC class & $\begin{array}{c}2000-2001 \\
\text { Area }\left(\mathrm{km}^{2}\right)\end{array}$ & $\begin{array}{c}2005-2006 \\
\text { Area }\left(\mathrm{km}^{2}\right)\end{array}$ & $\begin{array}{c}2011-2012 \\
\text { Area }\left(\mathrm{km}^{2}\right)\end{array}$ & $\begin{array}{l}\% \text { of variation } \\
\text { from } 2000-2001 \\
\text { and } 2005-2006\end{array}$ & $\begin{array}{l}\% \text { of variation } \\
\text { from } 2005-2006 \\
\text { and } 2011-2012\end{array}$ & $\begin{array}{l}\% \text { of variation } \\
\text { from } 2000-2001 \\
\text { and } 2011-2012\end{array}$ \\
\hline Agriculture & 13662.48 & 13642.76 & 13470.66 & -0.1 & -1.3 & -1.4 \\
\hline Builtup & 127.85 & 136.48 & 228.95 & 0.8 & 67.8 & 79.1 \\
\hline Barren land & 1706.85 & 1715.73 & 1721.5 & 0.5 & 0.3 & 0.9 \\
\hline
\end{tabular}

for lowering the soil moisture and thus depleting the ground water level (Verstraeten et al. 2008). Thus, increasing temperature causes increase in evapotranspiration (ET) and resulting in depletion in groundwater level (Gunawardhana and Kazama 2012).

Table 2 shows land use and land cover classification over the study area. These landuse classes were identified using Landsat ETM+ satellite data using supervised classification. The classes were sub-divided into three groups, namely; (i) agriculture, (ii) built-up and (iii) Barrenland. Compared to 2000-2001 and 2011-2012, it can be seen that built up area has been increased by about $80 \%$ over study area from 2000-2001 to 2011-2012, indicating heavy urbanization over study area. Urbinization may have a great impact on ground water level. Observed decline in ground water 
level may also be attributed to over-abstraction as reported by previous studies (Khazaei et al. 2004).

\section{Conclusion}

Present study reveals a significant increase in ground water level depletion over Ahmednagar district of Maharashtra. Ground water depletion shows coherent variability with temperature and ET. Ground water depletion over the study area has been observed with decrease in precipitation and ground water recharge. Increase in depletion of ground water level may also get affecated by increase in temperature, ET and urbinization. Present study report that Parner block of study area is critically affected by severe depletion in ground water level. Rate of ground water depletion has been accelerated during last decade due to a number of reasons discussed in this paper. Ground water management is essential to mitigate the problems related to depleted ground water level. This includes increasing water use efficiency, change in irrigation policy, ground water regulation, recycling of water, artificial recharge and mass awareness program.

\section{Acknowledgements}

We are grateful to CGWB for providing ground water level data. Precipitation data from TRMM and ET, Temperature data from MEERA Model reanalysis is thankfully acknowledged. We also thank NASA and NRSC for providing the satellite data. We are also grateful to CSIR-HRDG for funding this research under grant no 24(0350)/17/EMRII. Useful comments from anonymous reviewers helped in increasing the quality of this paper.

\section{References}

Adeleke O O, Makinde V, Eruola A O, Dada O F, Ojo A O and Aluko T J 2015 Estimation of groundwater recharges using empirical formulae in Odeda Local Government Area, Ogun State, Nigeria; Challenges 6(2) 271-281.

Goswami B N, Venugopal V, Sengupta D, Madhusoodanan M S and Xavier P K 2006 Increasing trend of extreme rain events over India in a warming environment; Science 314(5804) 1442-1445.

Goyal S K, Chaudhary B S, Singh O, Sethi G K and Thakur P K 2010 Variability analysis of groundwater levels - AGIS-based case study; J. Indian Soc. Remote Sens. 38(2) 355-364.

Gunawardhana L N and Kazama S 2012 Statistical and numerical analyses of the influence of climate variability on aquifer water levels and groundwater temperatures: The impacts of climate change on aquifer thermal regimes; Global Planet. Change 86 66-78.

Khazaei E, Mackay R and Warner J W 2004 The effects of urbanization on groundwater quantity and quality in the Zahedan aquifer, southeast Iran; Water Int. 29(2) 178188.

Mishra A K and Rafiq M 2017 Analyzing snowfall variability over two locations in Kashmir, India in the context of warming climate; Dyn. Atmos. Oceans 79 1-9.

Mishra A and Liu S C 2014 Changes in precipitation pattern and risk of drought over India in the context of global warming; J. Geophys. Res. Atmos. 119(13) 7833-7841.

Misstear B D R, Brown L and Daly D 2009 A methodology for making initial estimates of groundwater recharge from groundwater vulnerability mapping; Hydrogeol. J. 17(2) 275-285.

Panda D K, Mishra A and Kumar A 2012 Quantification of trends in groundwater levels of Gujarat in western India; Hydrol. Sci. J. 57(7) 1325-1336.

Patle G T, Singh D K, Sarangi A, Rai A, Khanna M and Sahoo R N 2015 Time series analysis of groundwater levels and projection of future trend; J. Geol. Soc. India 85(2) $232-242$.

Rafiq M and Mishra A 2016 Investigating changes in Himalayan glacier in warming environment: a case study of Kolahoi glacier; Environ. Earth Sci. 75(23) 1469.

Rafiq M and Mishra A K 2018 A study of heavy snowfall in Kashmir, India in January 2017; Weather 73(1) 15-17.

Salem G S A, Kazama S, Shahid S and Dey N C 2017 Impact of temperature changes on groundwater levels and irrigation costs in a groundwater-dependent agricultural region in northwest Bangladesh; Hydrol. Res. Lett. 11(1) 85-91.

Singh O and Kasana A 2017 GIS-based spatial and temporal investigation of groundwater level fluctuations under ricewheat ecosystem over Haryana; J. Geol. Soc. India 89(5) $554-562$.

Taylor R G, Scanlon B, Döll P, Rodell M, Van Beek R, Wada Y, Longuevergne L, Leblanc M, Famiglietti J S, Edmunds $\mathrm{M}$ and Konikow L 2013 Ground water and climate change; Nat. Clim. Change 3(4)322.

Thakur G S and Thomas T 2011 Analysis of groundwater levels for detection of trend in Sagar district, Madhya Pradesh; J. Geol. Soc. India 77(4)303-308.

Verstraeten W W, Veroustraete F and Feyen J 2008 Assessment of evapotranspiration and soil moisture content across different scales of observation; Sensors 8(1) 70 117.

Wang X J, Zhang J Y, Ali M, Shahid S, He R M, Xia X H and Jiang Z 2016 Impact of climate change on regional irrigation water demand in Baojixia irrigation district of China; Mitigation Adapt. Strat. Global Change 21(2) 233-247.

Yagbasan O 2016 Impacts of climate change on groundwater recharge in Küçük Menderes River Basin in Western Turkey; Geodin. Acta 28(3) 209-222. 